\title{
Hard Surface Layers by Pack Boriding and Gaseous Thermo-Reactive Deposition and Diffusion Treatments
}

Christiansen, Thomas Lundin; Bottoli, Federico; Dahl, Kristian Vinter; Gammeltoft-Hansen, N. B.; Laursen, M. B.; Somers, Marcel A. J.

Published in:

Materials Performance and Characterization

Link to article, DOI:

10.1520/MPC20160106

Publication date:

2017

Document Version

Peer reviewed version

Link back to DTU Orbit

Citation $(A P A)$ :

Christiansen, T. L., Bottoli, F., Dahl, K. V., Gammeltoft-Hansen, N. B., Laursen, M. B., \& Somers, M. A. J. (2017). Hard Surface Layers by Pack Boriding and Gaseous Thermo-Reactive Deposition and Diffusion Treatments. Materials Performance and Characterization, 6(4), 1-17. https://doi.org/10.1520/MPC20160106

\section{General rights}

Copyright and moral rights for the publications made accessible in the public portal are retained by the authors and/or other copyright owners and it is a condition of accessing publications that users recognise and abide by the legal requirements associated with these rights.

- Users may download and print one copy of any publication from the public portal for the purpose of private study or research.

- You may not further distribute the material or use it for any profit-making activity or commercial gain

- You may freely distribute the URL identifying the publication in the public portal 


\title{
Hard surface layers by pack boriding and gaseous thermo-reactive
}

\section{deposition and diffusion treatments}

Thomas L. Christiansen ${ }^{1}{ }^{*}$, Federico Bottoli ${ }^{1}$, Kristian V. Dahl ${ }^{1}$, Niklas B. Gammeltoft-Hansen ${ }^{1}$, Mads B. Laursen², Marcel A.J. Somers ${ }^{1}$

${ }^{1}$ Technical University of Denmark, Department of Mechanical Engineering, Produktionstorvet b.425, DK 2800 Kgs. Lyngby, Denmark

${ }^{2}$ TRD Surfaces, Agern allé 3, DK2970 Hørsholm, Denmark

*Corresponding author

\begin{abstract}
Thermo-reactive deposition and diffusion (TRD) and boriding are thermochemical processes that result in very high surface hardness by conversion of the surface into carbides/nitrides and borides, respectively. These treatments offer significant advantages in terms of hardness, adhesion, tribooxidation and high wear resistance compared to other conventional surface hardening treatments. In this work 4 different materials, ARMCO, AISI 409, Uddeholm ARNE® (AISI O1 equivalent) and VANADIS® 6 PM steel representing different classes of alloys, i.e. pure iron, stainless steel and tool steels, were subjected to TRD (chromizing \& titanizing) and boriding treatments. For the steels with low carbon content chromizing results in surface alloying with chromium, i.e. formation of a (soft) 'stainless' surface zone. Steels containing higher levels of carbon form chromium carbide (viz. $\mathrm{Cr}_{23} \mathrm{C}_{6}, \mathrm{Cr}_{7} \mathrm{C}_{3}$ ) layers with hardnesses up to $1800 \mathrm{HV}$. Titanizing of ARNE tool steel results in
\end{abstract}


a surface layer consisting of TiC with a hardness of approximately $4000 \mathrm{HV}$. Duplex treatments, where boriding is combined with subsequent (TRD) titanizing, result in formation of hard $\mathrm{TiB}_{2}$ on top of a thick layer of Fe-based borides. The obtained surface layers were characterized with X-ray diffraction, scanning electron microscopy, reflected light microscopy and micro-indentation.

\section{Keywords:}

Boriding; Thermo-reactive deposition and diffusion (TRD); Chromizing; Titanizing; $\mathrm{TiB}_{2}$

\section{Introduction}

Thermochemical surface engineering of metallic materials is widely applied for applications where components are exposed to (excessive) wear or where other surface characteristics are desired, e.g. fatigue and corrosion resistance [1]. Conventional and commonly applied methods include carburizing, carbo-nitriding and ferritic nitriding/nitrocarburizing in many different commercial variants. For applications where high hardness is needed, e.g. where excessive wear is encountered, boriding and thermo-reactive diffusion processes can be applied.

Boriding is a process where boron is diffused into a material resulting in formation of a compound layer consisting of hard borides of the elements present in the treated substrate. When the process is applied on steels, iron borides are formed with a hardness of more than $1600 \mathrm{HV}[2,3,4]$. The borides formed are typically $\mathrm{FeB}$ and $\mathrm{Fe}_{2} \mathrm{~B}$ as well as borides of the alloying elements, e.g. $\mathrm{Cr}$ and Mo $[2,3]$. For tribological applications a single layer of $\mathrm{Fe}_{2} \mathrm{~B}$ is usually preferred since it is less brittle than FeB [3,5]. Different process media are possible, including powder pack, salt bath and plasma. 
The Thermo Reactive Deposition and Diffusion (TRD) process was originally developed by Arai $[6,7]$ and is also known as the Toyota diffusion process. The substrate to be treated is typically immersed in a molten (borax) salt bath containing strong carbide or nitride forming elements. The carbide/nitride forming element (e.g. $\mathrm{V}, \mathrm{Nb}, \mathrm{Cr}$ etc.) reacts with the carbon or nitrogen in the base material to form a thin reaction layer of (hard) carbide or nitride. For example a vanadium carbide reaction layer formed by a TRD process has a hardness of around $3000 \mathrm{HV}$ and has excellent adhesion to the substrate as compared to PVD and CVD coatings. Typical thicknesses of TRD reaction layers are in the $2-14 \mu \mathrm{m}$ range. Due to the low thicknesses the life time will be limited under conditions where significant wear of the hard layer occurs [6]. The TRD process should not be confused with CVD processes [e.g. 8,9], where carbide layers are deposited onto a substrate and the carbon is provided by the gas atmosphere; in TRD the carbon (or nitrogen) is provided by the steel itself and diffusion of the carbide/nitride forming element into the surface of the steel, albeit to a limited extent, secured a diffusion bond between carbide/nitride reaction layer and the steel.

TRD processes typically make use of borax- or chloride-based salt-baths $[6,10,11,12]$, but the use of different deposition media can be found in the literature. Powder pack TRD processing has been applied as an alternative to salt bath, e.g chromizing for formation of hard chromium carbo-nitride layers [13] and powder pack vanadizing for growth of vanadium carbides [14,15]. Chromium carbide formation on martensitic stainless steels by different processes, viz. CVD and pack cementation, was investigated in Ref. [16].

Different variants of duplex processes can be found in literature where the steel is prenitrided/nitrocarburized/carburized prior to TRD processing, resulting in an accumulation of interstitial elements in the steel and thereby facilitating the formation of thicker wear layers for improved performance and/or enabling lower TRD processing temperatures [17,18,19,20, 21$]$. 
The combination of boriding and TRD processing has been shown to impart treated components with highly intriguing properties [22]. Vast improvement of wear performance of duplex treated steel has been achieved as compared with the individual TRD or boriding processes. However, these combination processes have not received much interest in the literature, which in part can be attributed to the niche-nature of the processes involved. Some examples of duplex processing can be found, e.g. borochromizing, borotitanizing and borovanadizing of stainless steel AISI 316L (chromizing, titanizing and vanadizing followed by boriding) [23], borovanadizing of AISI 8620 steel (boriding followed by vanadizing) [24], borochromizing of carbon steels (boriding followed by chromizing) [25] and borotitanizing of AISI 1040 steel (boriding followed by titanizing) [26]. Boriding niobizing (boroniobizing) of AISI H13 steel was shown to impart the material with a hightemperature stable wear resistant surface [27].

The present work investigates the response of 4 widely different classes of iron-based materials on powder-pack boriding and gaseous TRD treatments. Examples of combining boriding with TRD processing (boro-titanizing) are presented, showcasing the options for applying different materials combinations for surface engineering.

\section{Experimental}

\subsection{Materials}

Different steel classes were investigated, i.e. pure (ARMCO) iron, ferritic stainless steel AISI 409, Uddeholm ARNE® (AISI O1 equivalent) and VANADIS® 6 PM steel. The nominal compositions are given in Table 1. The tool steels ARNE and VANADIS were in a soft-annealed condition. 


\subsection{BORIDING}

Powder-pack boriding was performed in a ceramic tube furnace with a protective argon atmosphere. The pack mixture consisted of $90 \mathrm{wt} \%$ silicon carbide $(\mathrm{SiC})$ as filler, $5 \mathrm{wt} \%$ boron carbide $\left(\mathrm{B}_{4} \mathrm{C}\right)$ as boron source and $5 \mathrm{wt} \%$ potassium tetrafluoroborate $\left(\mathrm{KBF}_{4}\right)$ as activator. The employed silicon carbide was type green F800 (average grain size $6.5 \pm 1 \mu \mathrm{m}$ ) supplied by ESK Germany. Boron carbide from Hermann Starck grade HP with grain size $2.5 \mu \mathrm{m}$ was used and potassium tetrafluoroborate powder from Sigma-Aldrich. The chemicals were carefully weighed and mixed thoroughly before the treatments. The pack and samples were accommodated in a graphite crucible with a lid and then heated to $900^{\circ} \mathrm{C}$ using a heating rate of approximately $8^{\circ} \mathrm{C} / \mathrm{min}$. The duration of the boriding treatment was 16 hours, reflecting that a relatively low boriding temperature was used. After the treatment the crucible was furnace cooled to room temperature in flowing argon; cooling took at least 4 hours. The applied boriding process conditions are not intended to replicate industrial conditions; focus is on the hardening response of the investigated materials (viz. microstructural development).

\subsection{TRD - CHROMIZING AND TITANIZING}

TRD out-of-pack treatments were carried out under protective argon atmosphere. Reactive gasses were generated from halide activated packs, consisting of metal-source and halide activator (cf. Ref. 28). Ferrochrome (60wt\% $\mathrm{Cr}$ and $40 \mathrm{wt} \% \mathrm{Fe}$ ) and titanium grade 1 powder from Merck were used as metal sources for chromizing and titanizing, respectively. The generated gases were contacted with the samples to be treated. Treatments were performed at $1000^{\circ} \mathrm{C}$ for the duration of 4 hours followed by slow furnace cooling.

\subsection{CHARACTERIZATION}


The microstructures of the treated samples were investigated in cross-section with reflected light optical microscopy. The embedded samples were ground and polished by standard metallographic procedures. The prepared cross sections were etched with $2 \%$ nital, except for the stainless AISI 409 for which Kalling's reagent no. 1 (100 ml ethanol, $100 \mathrm{ml} \mathrm{32 \%} \mathrm{HCl}, 100 \mathrm{ml} \mathrm{H}_{2} \mathrm{O}$ and $4.5 \mathrm{~g}$ $\mathrm{CuCl}_{2}$ ) was used. Scanning electron microscopy back-scatter electron imaging and energy dispersive X-ray spectroscopy were carried out using a JEOL JSM-5000 microscope equipped with Oxford Instruments EDS equipment.

Microhardness indentation measurements were performed on a Future-Tech FM700 instrument using loads of $0.05,0.10$ or $0.25 \mathrm{~N}$.

X-ray diffractometry for phase identification was carried out using Bragg-Brentano symmetric and grazing incidence mode using a Bruker D8 AXS X-ray diffractometer equipped with Cr-anode and Göbel mirror in the incident beam.

\section{Results and interpretations}

\subsection{BORIDING}

Light optical micrographs (LOM) of the cross sections of the borided steels are given in Fig. 1. Clearly, the composition of the different materials plays a large role for the response of the treatment. The unalloyed ARMCO iron exhibits the characteristic "sawtooth" morphology of the borided case (indicated with an arrow in Fig. 1A) as generally observed on boriding iron (see e.g. [1]). The thickness of the case or boron-affected zone is approximately $150 \mu \mathrm{m}$. The core of the material is characterised by large ferrite grains, as a consequence of grain growth during the 
boriding treatment, as the iron was maintained in the ferrite region $\left(900^{\circ} \mathrm{C}\right)$ for the entire duration of the treatment. The ARNE tool steel (Fig. 1B) exhibits a sharper and more distinct interface between the borided case and the substrate. Indications of columnar growth of the boride can still be observed. The substrate is fully pearlitic due to the high carbon content and the slow cooling rate from the boriding process temperature, which for this steel lies within the austenite region. The case depth is approximately $100 \mu \mathrm{m}$. The main difference between ARMCO and ARNE is the carbon content (cf. Table 1) and the phase into which the boride layer is growing during treatment, i.e. ferrite vs. austenite.

The powder metallurgical high-alloyed VANADIS 6 tool steel is shown in Fig. 1C. The core structure is markedly different from the conventional ARNE tool steel as many small carbides are visible; these are mainly primary (stable) vanadium carbides. The borided case consists of different zones: an outermost zone (approximately $30 \mu \mathrm{m}$ thick) which is considered a continuous boride layer consisting of $\mathrm{FeB}$ and $\mathrm{Fe}_{2} \mathrm{~B}$, followed by a zone constituted of a network of borides or as discrete boride spheres (transition zone). The continuous outermost zone is again subdivided into a surface-adjacent zone $(\mathrm{FeB})$ which etches darker than the zone below $\left(\mathrm{Fe}_{2} \mathrm{~B}\right)$. The region of the substrate adjacent to the boron enriched zone has a slightly darker appearance, which could indicate a change in composition, e.g. carbon is accumulated ahead of the advancing boride case. The case depth of the boride zone is approximately $50-60 \mu \mathrm{m}$, which is significantly thinner than for the ARNE tool steel. This is attributed to the presence of substitutional alloying elements, viz. V and $\mathrm{Cr}$, and the presence of stable primary carbides impeding growth. The ferritic stainless steel AISI 409 (Fig. 1D) represents a totally different type of material compared to the tool steels as it does not contain carbon, but is alloyed with $\mathrm{Cr}$. The morphology of the boride case is represented by a continuous layer at the outermost surface with minor variations in etching response (cf. VANADIS) and a zone near the substrate consisting of many boride stringers/needles (transition zone). Grain 
growth has also occurred in the ferritic substrate during boriding; the material is fully ferritic at the processing temperature.

SEM images of the borided steels are given in Fig. 2. The same features are observed as revealed in LOM: The borided ARMCO and ARNE contain what appears to be a single phase boride case $\left(\mathrm{Fe}_{2} \mathrm{~B}\right)$, albeit with different morphologies (cf. above). A tendency for a sawtooth-like morphology is clearly observable for ARNE, although not as pronounced as for the unalloyed ARMCO. Between the boride teeth the substrate (etches white) contains discrete features with a spherical morphology (indicated with arrows in Fig. 2B). This could be interpreted as e.g. borocementite $\mathrm{Fe}_{3}(\mathrm{~B}, \mathrm{C})$. The VANADIS tool steel exhibits different contrast in the continuous surface adjacent boride layer; the outermost region appears darker indicating the presence of elements with lower atom number (density). This suggests the presence of borides with a higher boron to metal ratio (viz. FeB - see XRD below). The primary vanadium-rich carbides (dark) are still present in the boride layer (see arrows in Fig.2C), indicating that dissolution of VC is slow at the boriding temperature or that vanadium is not incorporated in the formed borides. For the AISI 409 a dark outermost zone $(\mathrm{FeB})$ is also apparent (cf. VANADIS). Below the continuous outermost boride zone, a region consisting of needles can be observed (transition zone). Possibly, these are Cr-based borides, implying that $\mathrm{Cr}$ has a higher affinity to boron than Fe. The discrete dark square particles (see arrows in Fig.2D) distributed in the material are $\mathrm{TiC}$ (the base material is stabilized by minor amounts of Ti).

Fig 3. Shows the EDS profiling of the major substitutional alloying elements in the surface region of VANADIS 6. Most notably is the change in Si composition, which is essentially nil in the first $30 \mu \mathrm{m}$ of the outmost layer. Si is apparently "pushed" out of this region and is accumulated deeper in the material. This zone of Si depletion is commensurate with the thickness of the continuous boride layer, indicating that $\mathrm{Si}$ is not incorporated in the formed borides. This is consistent with 
negligible solubility of $\mathrm{Si}$ in $\mathrm{Fe}$-based borides, $\mathrm{FeB}$ and $\mathrm{Fe}_{2} \mathrm{~B}$. It is unclear if the augmented $\mathrm{Si}$ content at a depth of approximately $40 \mu \mathrm{m}$ results in the formation of other phases (e.g.

silicoborides or silicides). The $\mathrm{V}$ and $\mathrm{Cr}$ profiles do not indicate formation of borides based on these elements in this region.

The resulting hardness-depth profiles of the borided materials are given Fig. 4. The profile for ARMCO is not included due to the sawtooth morphology of the borided case making depth profiling difficult. The hardness in the surface-adjacent zone of borided ARMCO is commensurate with what is obtained for ARNE. For the treated materials surface hardnesses ranging from approximately $1600 \mathrm{HV}$ to almost $2000 \mathrm{HV}$ can be observed. The highest values are obtained for the AISI 409 material. The depths are similar to the affected depths obtained by LOM and SEM. For both AISI 409 and VANADIS a transition zone exists where the hardness gradually decreases to the substrate hardness whereas for ARNE the transition is more abrupt, again this is consistent with the microstructural features observed with LOM/SEM. It should be noted that for the materials ARNE and VANADIS post hardening treatments should be carried out in order to enhance bulk hardness/strength. All treated materials obtain a high surface hardness by boriding.

X-ray diffractograms obtained in Bragg-Brentano mode are given in Fig. 5 for all borided samples. The information originates from the outmost part of the borided layer, i.e. the information depth is below $10 \mu \mathrm{m}$. For ARMCO and ARNE the surface consists of $\mathrm{Fe}_{2} \mathrm{~B}(\mathrm{C}-16)$, which is consistent with a medium-activity powder pack and a relatively long treatment time. The pack activity is expected to decrease over time which (eventually) will favour iron-rich $\mathrm{Fe}_{2} \mathrm{~B}$ boride over $\mathrm{FeB}$. There is also a continuous transport of boron by diffusion into the material which will lower the surface concentration if not replenished. This combination of (time-dependent) activity and inward 
diffusion evidently results in formation of $\mathrm{Fe}_{2} \mathrm{~B}$.For the high-alloyed materials AISI 409 and VANADIS a mixture of $\mathrm{Fe}_{2} \mathrm{~B}(\mathrm{C}-16)$ and $\mathrm{FeB}(\mathrm{B}-27)$ is found. Hence the presence of substitutional alloying elements will result in a higher activity of boron in the solid state and/or impede mobility of diffusing boron. Borides based on vanadium or chromium are seemingly not present in the near surface region. Here it should be noted that the two-metal borides systems $\mathrm{Cr}_{2} \mathrm{~B}-\mathrm{Fe}_{2} \mathrm{~B}$ and $\mathrm{CrB}-\mathrm{FeB}$ show partial solubility. This could suggest that $\mathrm{Cr}$ to some extent is dissolved in the in Fe-based borides; vanadium is predominantly found in the form of (undissolved) carbides (cf. EDS/SEM). Dissolution of $\mathrm{Cr}$ ( or $\mathrm{Cr}_{2} \mathrm{~B}$ ) in the $\mathrm{Fe}_{2} \mathrm{~B}$ is consistent with the observed slight peak shift for the $\mathrm{Fe}_{2} \mathrm{~B}$ phase for VANADIS and AISI 409 (see e.g. the peak at $143^{\circ}$ ).

Based on the diffractograms it is unclear to what extent carbon influences the boride formation. Both iron-based borides $\mathrm{FeB}$ and $\mathrm{Fe}_{2} \mathrm{~B}$ have an appreciable solubility of carbon and in cementite, $\mathrm{Fe}_{3} \mathrm{C}$, boron can substitute for carbon up to 80 at. $\% \mathrm{~B}$ at $1000^{\circ} \mathrm{C}$ [29]. Boron can in this respect play the role of both interstitial and substitutional element (replace both $\mathrm{C}$ and $\mathrm{Fe}$ ). Only the outermost layer of the entire borided case is probed by the X-rays, meaning that different phase constitutions could be found deeper in the boron-containing zone.

\subsection{THERMO-REACTIVE DEPOSITION AND DIFFUSION}

TRD processes can be considered an alternative to boriding processes as they can give rise to very hard, but generally thinner, surface layers consisting of hard nitrides/carbides.

\subsubsection{Chromizing}

All the four materials were also treated with the chromizing process. Light optical micrographs of cross sections are given in Fig. 6. For ARMCO a distinct chromized layer with a thickness of nearly 
$40 \mu \mathrm{m}$ can be observed. This layer contains relatively large near-surface porosities (indicated by arrows in Fig.6A), which can be attributed to the aggressive behaviour of the halide containing gas atmosphere provided by the pack (detrimental side-effect). Only the un-alloyed ARMCO material exhibits this effect. The two tool steels with high contents of carbon develop a highly uniform layer (denoted $\mathrm{Cr}_{\mathrm{x}} \mathrm{C}_{\mathrm{y}}$ ) which is unaffected by the etching reagent. The thickness obtained on ARNE is 10$12 \mu \mathrm{m}$ and for VANADIS $8-10 \mu \mathrm{m}$. The substrate has the same microstructure as for boriding, i.e. pearlite due to slow cooling from the chromizing process temperature of $1000^{\circ} \mathrm{C}$ (particularly evident for ARNE). The 12\% chromium containing ferritic AISI 409 stainless steel has a surface zone which gradually fades into the substrate, indicating an augmented Cr-content in the ferrite, which changes the etching response.

X-ray diffractograms of the chromized materials are given in Figs. 7 (Bragg-Brentano) and 8 (grazing incidence). The hardness depth profiles and EDS Cr-composition depth profiles are given in Figs. 9 and 10, respectively. The two materials without carbon, i.e. ARMCO and AISI 409 are clearly ferritic and for ARMCO a minute fraction of chromium carbide $\left(\mathrm{M}_{7} \mathrm{C}_{3}\right.$ structure $)$ in the surface can also be observed (Fig. 8). For ARMCO this implies that the surface zone essentially can be characterised as a ferritic stainless steel. From the EDS Cr profiling the Cr rich surface layer reaches up to above $25 \mathrm{wt} \% \mathrm{Cr}$ and with a plateau of above $15 \mathrm{wt} \% \mathrm{Cr}$. This corresponds to a super-ferritic stainless steel material. The hardness profile shows a slight increase in the Cr-enriched zone which can be attributed to solid solution hardening by dissolving $\mathrm{Cr}$; the core hardness is around $130 \mathrm{HV}$ and in the Cr-rich surface zone it is around $200 \mathrm{HV}$. The minute fraction of $\mathrm{M}_{7} \mathrm{C}_{3}$, due to minor impurities of carbon in the material, is expected in the outermost surface zone (cf. grazing incidence XRD) and is not included in the hardness measurements (in cross section). For the ferritic stainless steel AISI 409 the Cr content is clearly augmented, as XRD shows that the surface zone maintains its ferritic structure. The EDS profiling yields similar $\mathrm{Cr}$ surface 
concentration as for ARMCO, i.e. above $25 \mathrm{wt} \%$. The $\mathrm{Cr}$ content in the diffusion zone gradually drops to the $\mathrm{Cr}$ content of the base material of $12 \mathrm{wt} \%$. It is evident that the surface concentration of Cr obtained in these materials is controlled by the activity of the gaseous atmosphere provided by the used pack chemistry. The two high-carbon tool steels develop a surface layer consisting of $\mathrm{M}_{7} \mathrm{C}_{3}$ $\left(\mathrm{Cr}_{7} \mathrm{C}_{3}\right)$ which is very hard, hardness values in the range 1600-1800 HV are obtained in the grown carbide layer (Fig. 9). This is also evident from the EDS profiling where the surface concentration of $\mathrm{Cr}$ reaches around $80 \mathrm{wt} \%$, which is consistent with formation of a carbide layer. There is a clear gradient in chromium content in the $\mathrm{M}_{7} \mathrm{C}_{3}$ carbide layer; the $\mathrm{Cr}$ content is highest near the surface and gradually drops to around $40 \mathrm{wt} \%$ at the carbide substrate interface. This implies that $\mathrm{Fe}$ is also present in the $\mathrm{M}_{7} \mathrm{C}_{3}$ carbide; $\mathrm{M}_{7} \mathrm{C}_{3}$ has a relatively large capacity for Fe. For the VANADIS a slight drop in Cr concentration near the surface can be observed, which can be attributed to incorporation of Fe due to local condensation of iron-rich gaseous species during cooling. The hardness of the core reflects the presence of a fully pearlitic structure.

\subsubsection{Titanizing}

An example of the microstructure of a TRD titanized ARNE tool steel is given in Fig. 11. The concept is the same as for chromizing. A uniform reaction layer of cubic $\mathrm{TiC}$ has grown in the surface of the steel having a thickness of $10-12 \mu \mathrm{m}$. The hardness measured in cross section is around $4000 \mathrm{HV}_{0.10 \mathrm{~N}}$, which is much higher than what can be obtained for TRD chromizing treatments. An interesting feature not observed for TRD chromized ARNE is the thin zone below the TiC layer which appears decarburized (indicated by arrows). This phenomenon could be due to stabilization of ferrite by $\mathrm{Ti}$ at the processing temperature, thus creating a carbon-free zone or alternatively by decarburization during cooling. 


\subsection{DUPLEX PROCESSES - BOROTITANIZING}

The possibility of combining a boriding treatment with TRD is intriguing as it has been claimed that this combination can result in highly improved wear properties (compared to the individual treatments). The concept is to firstly subject the component to a boriding treatment where a (deep) boride case (typically $\mathrm{FeB}, \mathrm{Fe}_{2} \mathrm{~B}$ ) is produced. In the second step the borided component is subjected to a TRD treatment; boron is then used instead of, typically, carbon for growing the TRD layer. Obviously, many different combinations are possible with this concept. Herein, the concept is illustrated for the interstitial-free materials ARMCO and AISI 409. The TRD process titanizing is deliberately chosen as Ti-borides are known to be extremely hard and possess special high temperature properties (viz. very high melting point for $\mathrm{TiB}_{2}$ ). In principle chromizing could also be used, but the Cr-borides have hardness values similar to the iron-borides. Fig 12 shows LOM micrographs of borided and subsequently titanized ARMCO. The duplex treatment is clearly visible from the microstructure; the iron-boride case $\left(\mathrm{Fe}_{2} \mathrm{~B}\right)$ has become thicker by redistribution of boron and a new uniform layer has formed on top. The thickness of the formed surface layer is around 6-8 $\mu \mathrm{m} . \mathrm{X}$-ray diffraction phase analysis (not shown) reveals that the surface region consists of hexagonal $\mathrm{TiB}_{2}(\mathrm{C}-32), \mathrm{Fe}_{2} \mathrm{~B}$ and ferrite and with indications of $\mathrm{Fe}_{2} \mathrm{Ti}$ and $\mathrm{TiC}$. It is interpreted as the outermost continuous layer is predominantly $\mathrm{TiB}_{2}$ (together with a minor fraction of $\mathrm{TiC}$ and possibly $\mathrm{Fe}_{2} \mathrm{Ti}$ ) and $\mathrm{Fe}_{2} \mathrm{~B}$ originates from deeper in the material, i.e. the (thick) supporting ironbased boride layer. From the micrographs in Fig 12 it can be observed that below the outmost continuous $\mathrm{TiB}_{2}$ layer the $\mathrm{Fe}_{2} \mathrm{~B}$ is partly dissolved and exhibits network morphology in a (soft) ferrite matrix (the extent of this zone is indicated with arrows in Fig. 12B). This is consistent with growth of $\mathrm{TiB}_{2}$ by dissolution of less stable $\mathrm{Fe}_{2} \mathrm{~B}$. Hardness measurements performed in cross sections with loads of $0.05 \mathrm{~N}$ and $0.1 \mathrm{~N}$ give indications of very high hardness; here it should be 
noted that the layer is relatively thin and good practise for performing microhardness testing cannot be obeyed. However, hardness values in the range 4500-5000 HV were consistently observed commensurate or higher than for TiC (cf. section 3.2.2). This corresponds well with the value of $4525 \mathrm{HV}_{0.05 \mathrm{~N}}( \pm 284)$ reported in ref.[26]

A similar duplex treatment was performed on AISI 409, which is shown in Fig.13 (LOM \& SEM). The same behaviour as for ARMCO is observed for the Cr-alloyed material. The original boride case has become slightly thicker and a new continuous $\mathrm{TiB}_{2}$ layer has formed at the surface. X-ray diffraction analysis (not shown) reveals exclusively the phases $\mathrm{TiB}_{2}, \mathrm{Fe}_{2} \mathrm{~B}$ and ferrite; cf. the explanation above.

\section{Discussion}

Two different types of processes were investigated in this work, i.e. boriding and TRD. Boriding is essentially a process where the interstitial element boron is incorporated into the surface of the treated material resulting in a compound layer (and a diffusion zone). TRD is conceptually different from solution of interstitials, because a metallic element with a high affinity to interstitials is supplied from an external medium (here: gaseous atmosphere) and reacts with the interstitials supplied from the substrate leading to inward and outward growth of a hard reaction layer (typically a carbide). Four different materials representing different alloy classes were used to illustrate the different responses.

For boriding all type of materials were surface hardened by formation of Fe-based boride compounds, viz. $\mathrm{Fe}_{2} \mathrm{~B}$ and $\mathrm{FeB}$. The hard boride cases were relatively thick and will provide enhanced wear resistance. The applied chromizing treatment had different responses depending on 
the alloy composition. The two materials without interstitials, i.e. ARMCO and AISI 409 resulted in surface alloying with chromium without formation of a hard surface layer/zone; this type of treatment can be classified as "soft-chromizing" and is not a TRD process. For the two tool steels the chromizing treatment resulted in development of very hard chromium carbide layers, which is representative of classical TRD; this can also be classified as "hard-chromizing". Hence, the boriding and chromizing treatments offer different responses and the treatments clearly have to be "paired" with the materials to be treated. The soft-chromizing will not provide any significant hardness increase or wear resistance, but it will provide superior corrosion resistance as the surface of the treated material essentially becomes a super-ferritic stainless steel. This concept entails that a relatively cheap material can be used and subsequently treated to provide high corrosion resistance. The hard chromizing treatment will provide very high wear resistance due to the presence of the hard carbides. In addition the corrosion resistance will be improved as the chromium carbide is corrosion resistant. The thickness of the TRD hard layers is typically significantly lower than for boriding treatments. However, for the titanizing treatment it was shown that hardness values twice as high as for boriding could be obtained. For materials with low carbon contents, TRD processes can still be an option if a pre-treatment is applied prior to the process. Carbon/nitrogen can in principle be added by applying a pre-nitriding/(nitro)carburizing process.

For both boriding and TRD of heat treatable steels, such as the investigated tool steels, a post hardening treatment should be introduced in order to harden the core. This is indeed an option for both types of treatments as the hard boride/carbide case will not spall off during the treatment.

It is clear that the two types of treatments, boriding and TRD, offer special advantages; boriding gives a relatively deep hard case whereas TRD gives layers with excellent adherence with hardness values up to $4000 \mathrm{HV}$. Obviously other specific chemical/physical properties can be accomplished by choosing the pertinent materials system, e.g. low friction, high temperature stability etc. 
Combination of boriding and TRD has previously been stated to offer unique materials properties [22]. Besides the chemical and physical effects of mixed interstitial/substitutional systems also the concept of combining a thick supportive layer (boride layer) and a very hard thin surface layer (TRD layer) is highly interesting. It is shown in the present work that special types of borides can form, viz. $\mathrm{TiB}_{2}$ can be grown on a borided iron-based material. The $\mathrm{TiB}_{2}$ is significantly harder than the iron based-borides and has a very high melting point, which will impart the material with good high-temperature properties. Also, other types of materials combinations can be envisioned by introducing other TRD processes ( $\mathrm{W}, \mathrm{Nb}, \mathrm{V}$, etc - see also the introduction). The boriding can be considered as a pretreatment where interstitials (boron) are supplied to the material concomitant with the formation of compound zone. Most materials can form borides implying that a process like borotitanizing is widely applicable for providing high surface hardness via formation of $\mathrm{TiB}_{2}$.It could be suggested that it would be favourable to have the boron rich FeB phase (high activity pack) in order to avoid a (soft) denuded ferrite zone under the developing $\mathrm{TiB}_{2}$ hard surface layer.

The scope of this work is not to address the properties of the materials treated by duplex methods but to illustrate the concept. Ostensibly, the boro-titanized materials will have extreme wear properties; the duplex processes can be considered to represent the best of both worlds.

\section{Conclusions}

Four different types of steels, ARMCO-Fe, Uddeholm ARNE \& VANADIS tool steels and ferritic stainless AISI 409 were subjected to boriding and TRD-type processes. All materials formed a hard iron-based boride layer after boriding. For the materials containing carbon (tool steels), TRD processing resulted in formation of a hard chromium or titanium carbide layer for chromizing and titanizing, respectively. The interstitial-free materials ARMCO-Fe and AISI 409 were soft- 
chromized resulting in a stainless steel surface zone with up to above $25 \mathrm{wt} \% \mathrm{Cr}$ in solid solution; no hard layers were formed. Combination of boriding and TRD titanizing (duplex boro-titanizing) was shown to result in a very hard surface layer of $\mathrm{TiB}_{2}$ on top of a thick and hard zone of Fe-based borides. Such duplex treatments are considered highly attractive and should be the focus of future research.

\section{Tables and figure captions:}

TABLE 1. Nominal composition (in wt $\%$ ) of the investigated materials.

\begin{tabular}{|c|c|c|c|c|c|c|c|c|c|}
\hline & C & Mn & $\mathrm{Cr}$ & $\mathbf{W}$ & $\mathbf{V}$ & $\mathbf{N i}$ & $\mathbf{T i}$ & $\mathbf{S i}$ & Mo \\
\hline ARMCO & 0.02 & 0.02 & - & - & - & & & & \\
\hline $\begin{array}{l}\text { ARNE (AISI } \\
\text { O1) }\end{array}$ & 0.95 & 1.1 & 0.6 & 0.6 & 0.1 & & & & \\
\hline AISI 409 & 0.01 & - & 11.5 & - & - & 0.1 & 0.2 & & \\
\hline VANADIS 6 & 2.1 & 0.4 & 6.8 & & 5.4 & & & 1 & 1.5 \\
\hline
\end{tabular}

Figure 1. LOM - boriding at $900^{\circ} \mathrm{C}$. A) ARMCO Fe. B) ARNE. C) VANADIS 6. D) AISI 409.

Figure 2. SEM - boriding at $900^{\circ} \mathrm{C}$. A) ARMCO Fe. B) ARNE. C) VANADIS 6. D) AISI 409.

Figure 3. EDS analysis; profiling. Borided VANADIS 6.

Figure 4. Hardness depth profiles. Boriding.

Figure 5. XRD. Boriding

Figure 6. LOM - Chromizing at $1000^{\circ} \mathrm{C}$. A) ARMCO Fe; B) ARNE. C) VANADIS 6 D) AISI 409

Figure 7. XRD (Bragg-Brentano geometry). Chromizing.

Figure 8. XRD (Grazing incidence). Chromizing 
Figure 9. Hardness depth profiles. Chromizing

Figure 10. Chromium composition profiles (EDS mapping). A) TRD hard-chromizing (ARNE \& VANADIS 6). B) Soft-chromizing (ARMCO \& AISI 409).

Figure 11. LOM - Titanizing of ARNE at $1000^{\circ} \mathrm{C}$; different magnifications.

Figure 12. Duplex processing of ARMCO. Boriding followed by TRD titanizing "borotitanizing". Different magnifications (LOM).

Figure 13. Duplex processing of AISI 409. Boriding followed by TRD titanizing "borotitanizing". A) LOM. B) SEM.

\section{REFERENCES:}

[1] E.J. Mittemeijer, M.A.J. Somers- “Thermochemcial Surface Engineering of Steels”, WoodHead Publishing, ISBN 978-0-85709-592-3, (2015) 827 pages.

[2] A. K. Sinha. "Boriding (Boronizing)", Heat Treating, ASM Handbook, ASM Intl., 4 (1991) 437-447.

[3] U. Sen, S. Sen, "The fracture toughness of borides formed on boronized cold work tool steels", Materials Characterization 50(4-5) (2003) 261-267.

[4] V. Jain, G. Sundararajan, "Influence of the pack thickness of the boronizing mixture on the boriding of steel”, Surface and Coatings Technology 149(1) (2002) 21-26.

[5] S. Sen, I. Ozbek, U. Sen, C. Bindal, "Mechanical behavior of borides formed on borided cold work tool steel”, Surface and Coatings Technology 135(2-3) (2001) 173-177. 
[6] N. Komatsu, T. Arai, M. Mizutani "Process of forming a carbide layer of vanadium, niobium or tantalum, upon a steel surface", US3719518A (Priority from Japanese patent application JP19690087805 19691101), 1973.

[7] T. Arai, Chapter 19 “ The Thermo-Reactive Deposition and Diffusion Process for Coating Steels to Improve Wear Resistance”, in Thermochemical Surface Engineering of Steels, E.J. Mittemeijer and M.A.J. Somers (2015).

[8] H.E. Hintermann, "Tribological and Protective Coatings by Chemical Vapour Deposition", Thin Solid Films 84 (1981) 215-243.

[9] H. Berndt, A.-Q. Zeng, H.-R. Stock and P. Mayr, "Vanadium carbide films produced by plasmaassisted metal-organic chemical vapour deposition”, JOURNAL DE PHYSIQUE IV, Colloque C3, supplement au Journal de Physique 11, Volume 3, August 1993, 313-320.

[10] X.S. Fan, Z.G. Yang, Z.X. Xia, C. Zhang, H.Q. Che, “The microstructure evolution of VC coatings on AISI H13 and 9Cr18 steel by thermo-reactive deposition process", Journal of Alloys and Compounds, 505 (2010) 15-18.

[11] F.A.P. Fernandes, J. Gallego, C.A. Picon, G. Tremiliosi Filho, L.C. Casteletti, "Wear and corrosion of niobium carbide coated AISI 52100 bearing steel”, Surface and Coatings Technology 277 (15) (2015) 112-117.

[12] X.S. Fan, Z.G. Yang, C. Zhang, Y.D. Zhang, H.Q. Che, "Evaluation of vanadium carbide coatings on AISI H13 obtained by thermo-reactive deposition/diffusion technique”, Surface and Coatings Technology, 205 (2010) 641-646.

[13] F. A. P. Fernandes, S. C. Heck, C. A. Picon, G. E. Totten and L. C. Casteletti, "Wear and Corrosion Resistance of Pack Chromised Carbon Steel”, Surface Engineering 28(5) 2012 313-317. 
[14] A. Mlynarczak, K. Jastrzebowski, "BILDUNG UND WACHSTUM VON VANADIUMKARBIDSCHICHTEN BEIM VANADIEREN VON WERKZEUGSTAEHLEN"

("Formation and Growth of Vanadium Carbide Layers in Vanadium Coating of Tool Steels"), Neue Huette, 25(7) (1980) 259-262.

[15] Z. Glowacki, K. Jastrzebowski, “Keimbildung und Wachstum von Vanadincarbiden auf 0,8\% C enthaltendem Austenit” Werkstofftechnik, Arch. Eisenhüttenwes. 55 (5) (1984) 217-222.

[16] A.B. Smith, A. Kempster, J. Smith, B. Mathiesen, J. Koh, G.W. Crichlow," Characteristics of Chromium Carbide Coatings Produced on a Martensitic Stainless Steel by Different Deposition Processes", Proceedings of the 13th International Plansee Seminar Vol.3 (1993) 129-144

[17] B. Chicco, W.E. Borbidge, E. Summerville, "Experimental study of vanadium carbide and carbonitride coatings”, Materials Science and Engineering A266 (1999) 62-72.

[18] K.V. Dahl, A.E. Barington, T.L. Christiansen: "Thermochemical treatments for combating extreme wear - boriding and vanadizing", Proceedings - 29th International Conference on Surface Modification Technologies, 10-12 June 2015, Copenhagen, Denmark, 162-170.

[19] D.M. Fabijanic, G.L. Kelly, P.D. Hodgson, “A new Low-Temperature Duplex Surface Treatment”, IndustrialHeating.com Oct. (2004) 29- 31.

[20] P.C. King, R.W. Reynoldson, A. Brownrigg, J. M. Long, “Cr(N,C) diffusion coating formation on pre-nitrocarburised H13 tool steel”, Surface and Coatings Technology 179 (2004) 18-26.

[21] U. Sen, “Thermo-Reactive Diffusion Vanadium Nitride Coatings on AISI 1020 Steel”, Key Engineering Materials Vols. 264-268 (2004) pp 577-580. 
[22] R. Chatterjee-Fischer, "Time to take a look at Multicomponent Boriding”, Metal Progress April (1986) 24-26.

[23] V. Samadi and A. Habibolahzade, "Evaluation of microstructures and wear properties of duplex boride coatings”, Materials Science and Technology 26(1) 2010 41-46.

[24] S. Sen, "The characterization of vanadium boride coatings on AISI 8620 steel”, Surface \& Coatings Technology 190 (2005) 1-6.

[25] V. D. Kal'ner, M. G. Karpman, and S. D. Kulazhenkov, "Successive Borochromizing of Carbon Steels", Translated from Fiziko-Khimicheskaya Mekhanika Materialov, NovemberDecember, 1986 22(6) 6 24-26. Original article submitted December 23, 1985.

[26] O. Kon, S. Pazarlioglu, M. Durmaz, U. Sen, S. Sen, "Structural Characterization of BoroTitanized AISI 1040 Steel”, Acta Physica Polonica A 127(4) (2015) 1211-1213.

[27] G.S. Takeya, F.E. Mariani, A.L. Neto, G.E. Totten, L.C. Casteletti, ”Characterization of Coatings obtained by boriding niobizing treatment of an AISI H13 steel”, Materials Performance and Characterization, 2016, doi:10.1520/MPC20150066.

[28] M.B. Laursen, K.V. Dahl, T.L. Christiansen, M.A.J. Somers, ”Surface layers produced by outof-pack treatment”, Danish patent application PA2015 70529, 2016.

[29] H.J. Goldschmidt "Interstitial Alloys", 1967. 
Fig1.

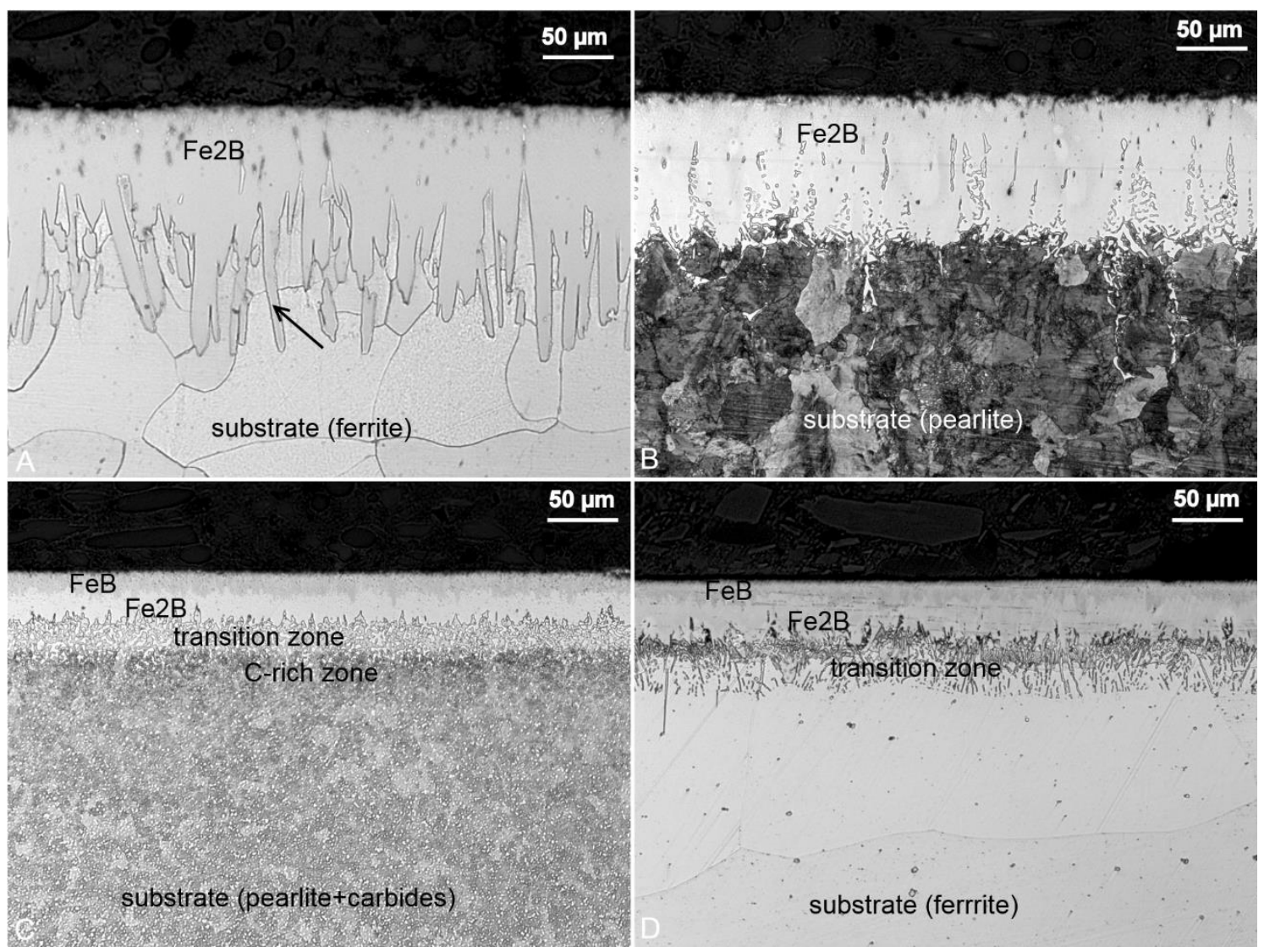


Fig.2

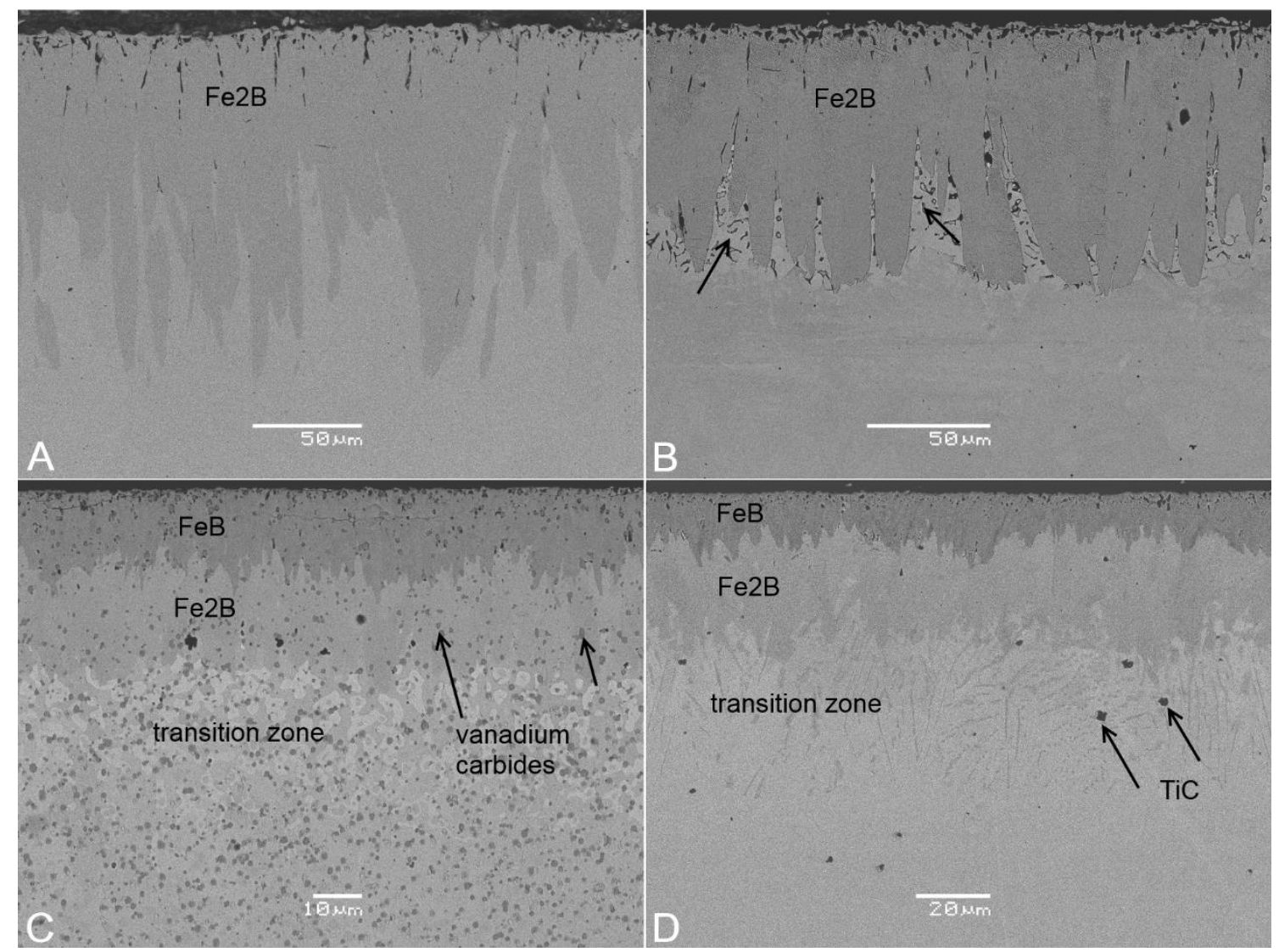


Fig.3

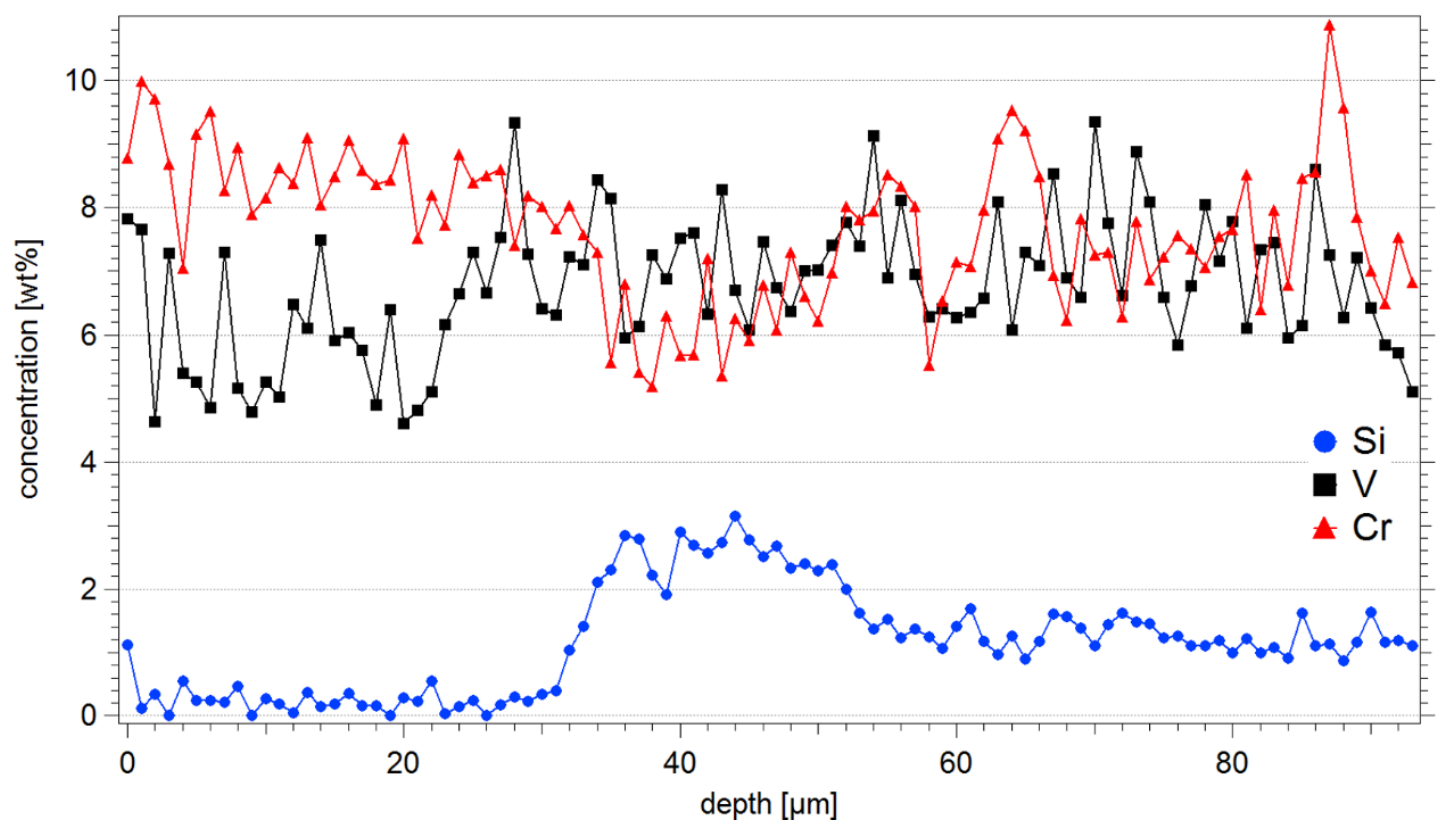


Fig.4

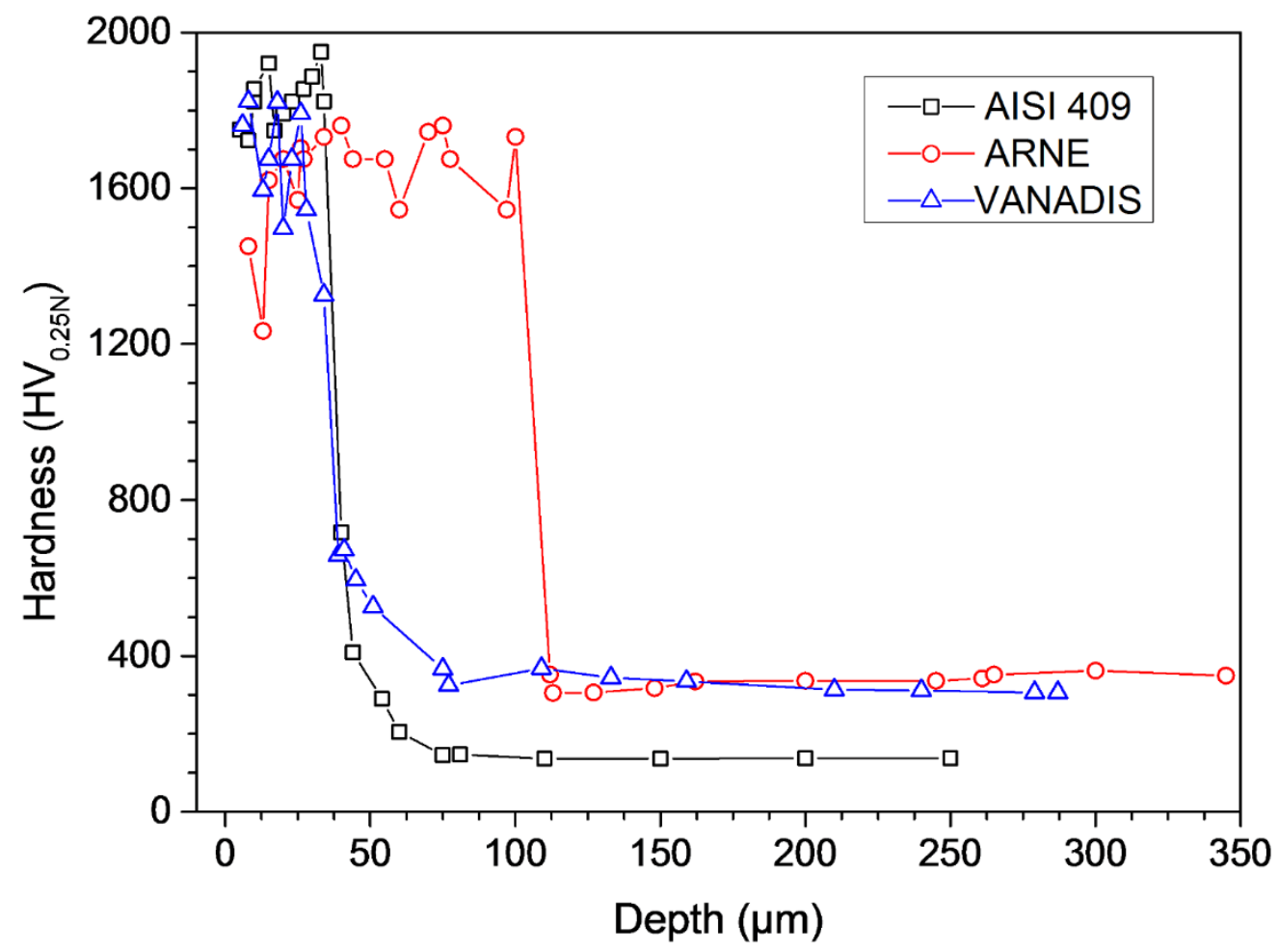


Fig.5

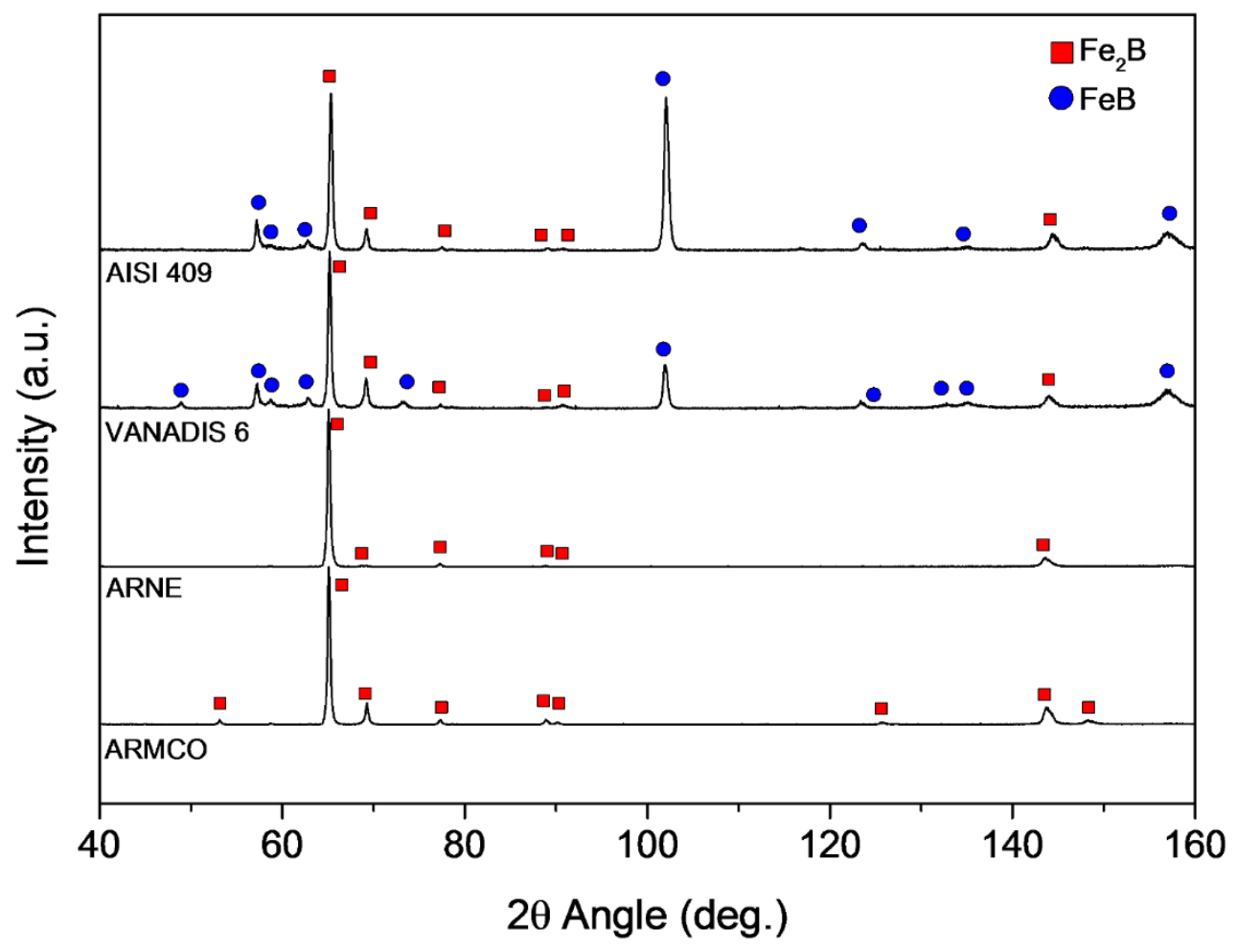


Fig.6




Fig.7

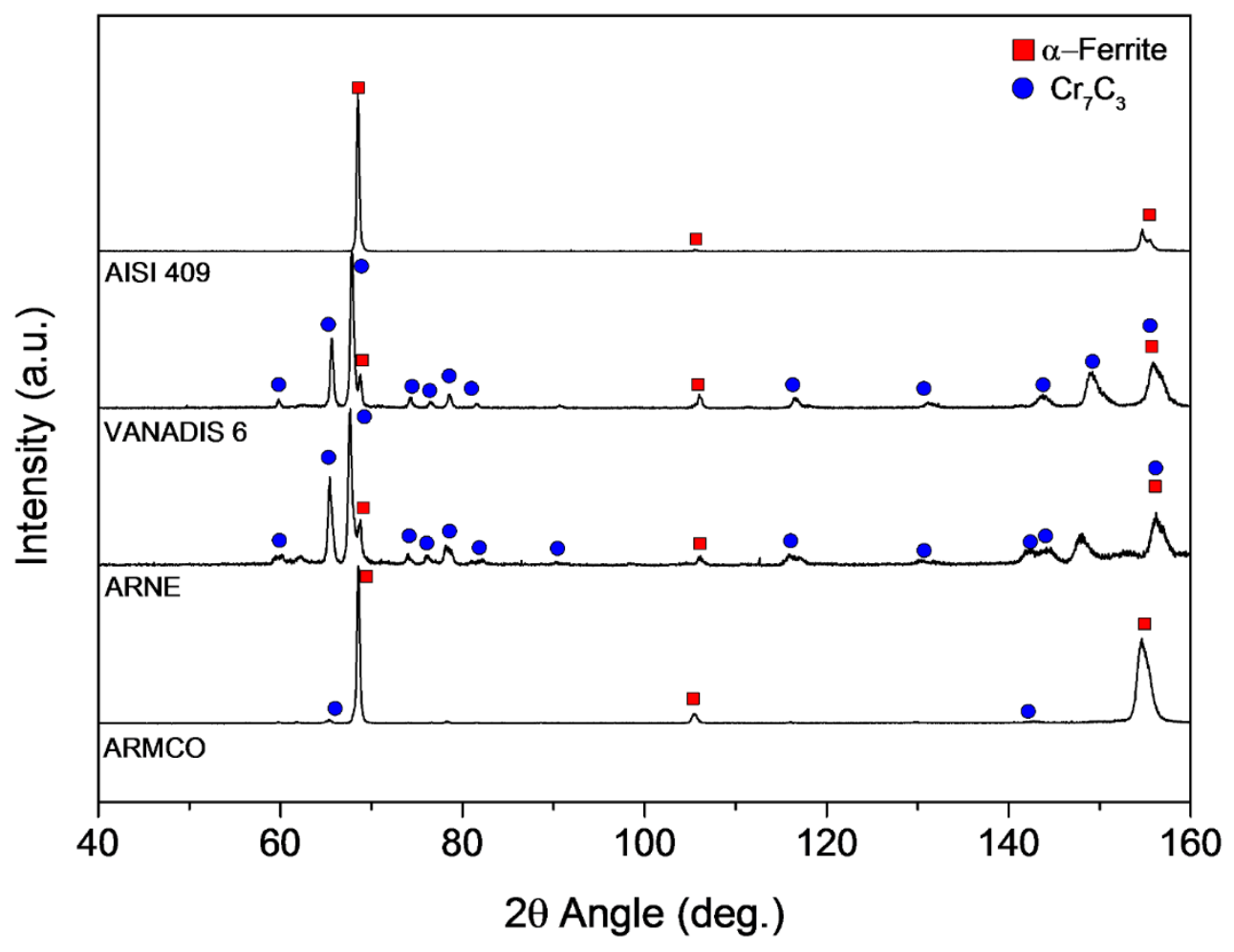


Fig.8

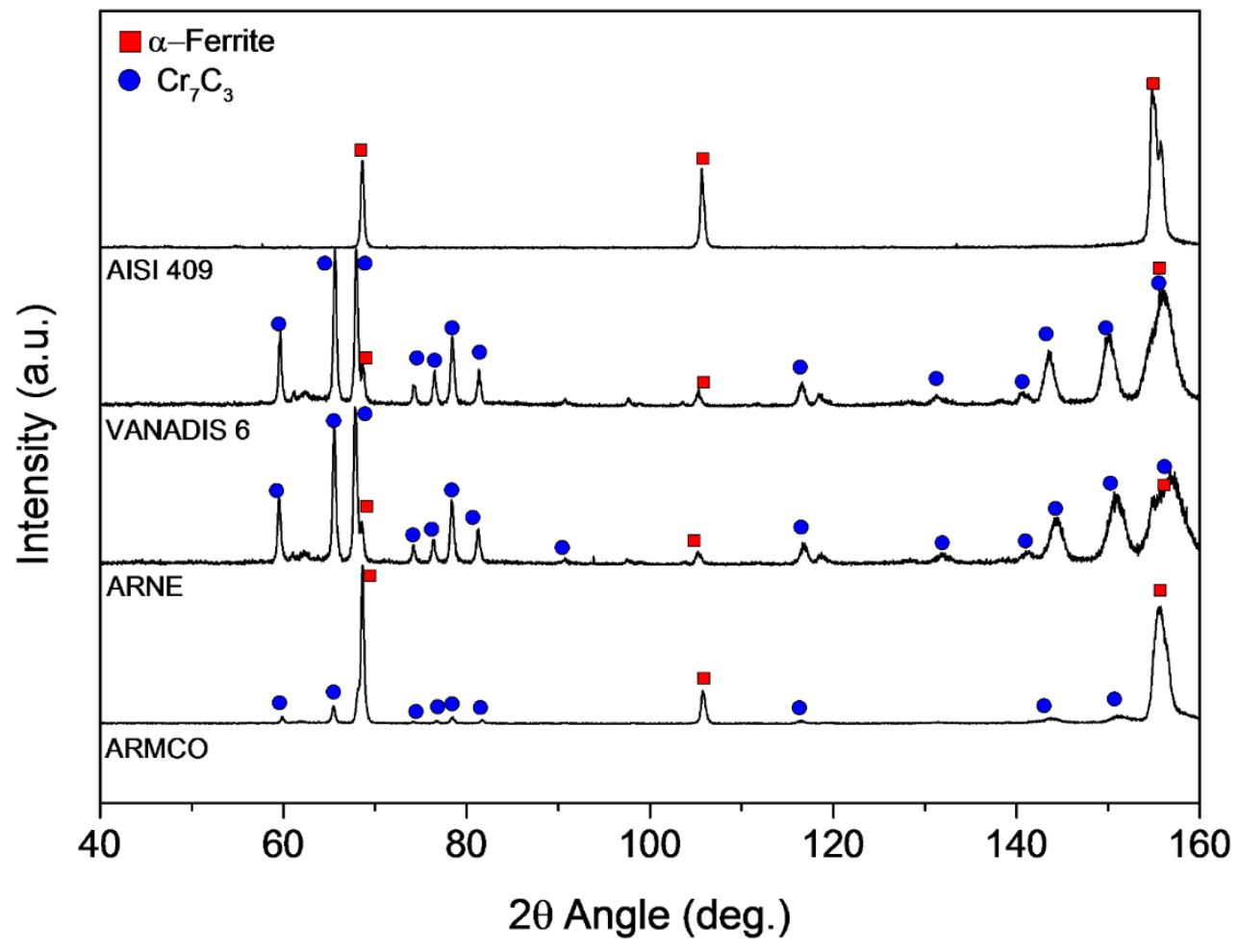


Fig.9

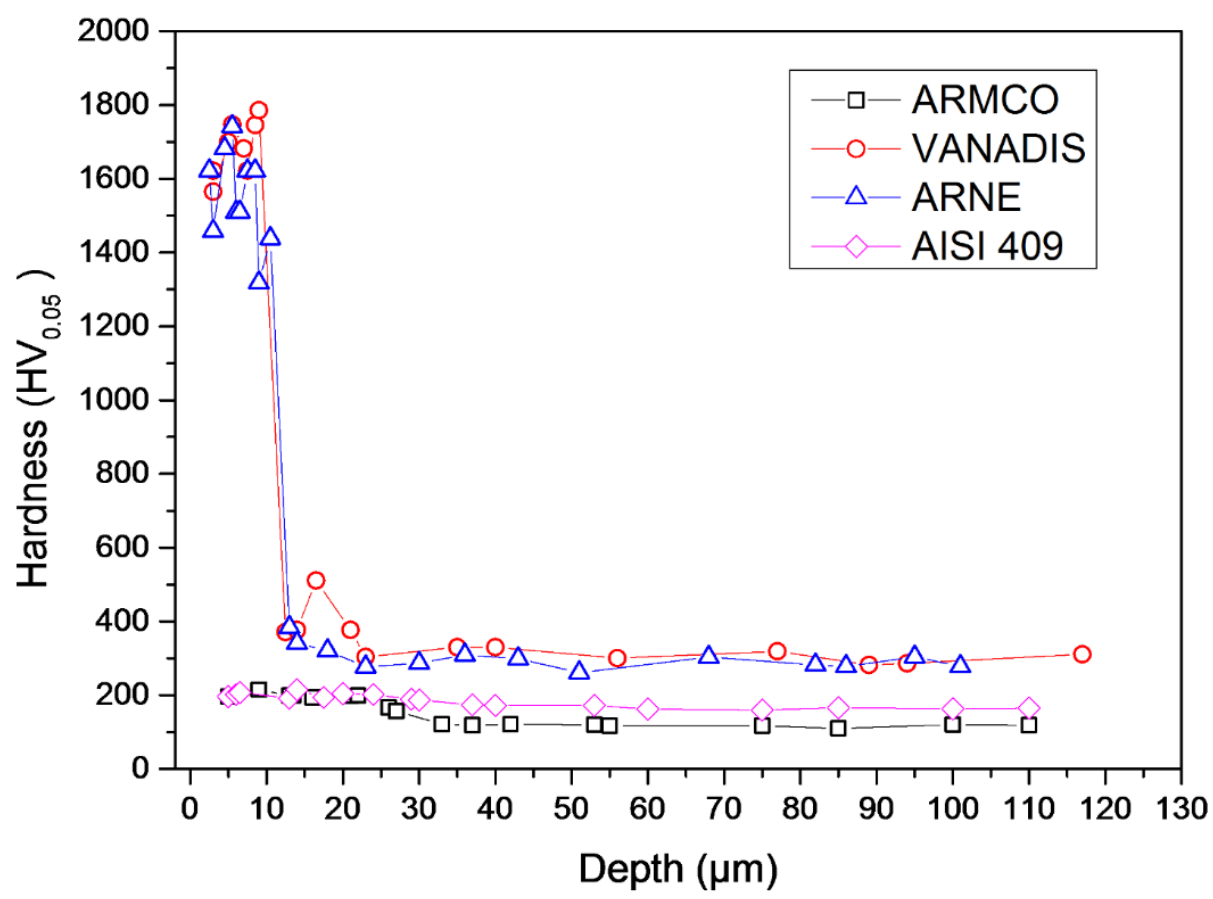


Fig.10
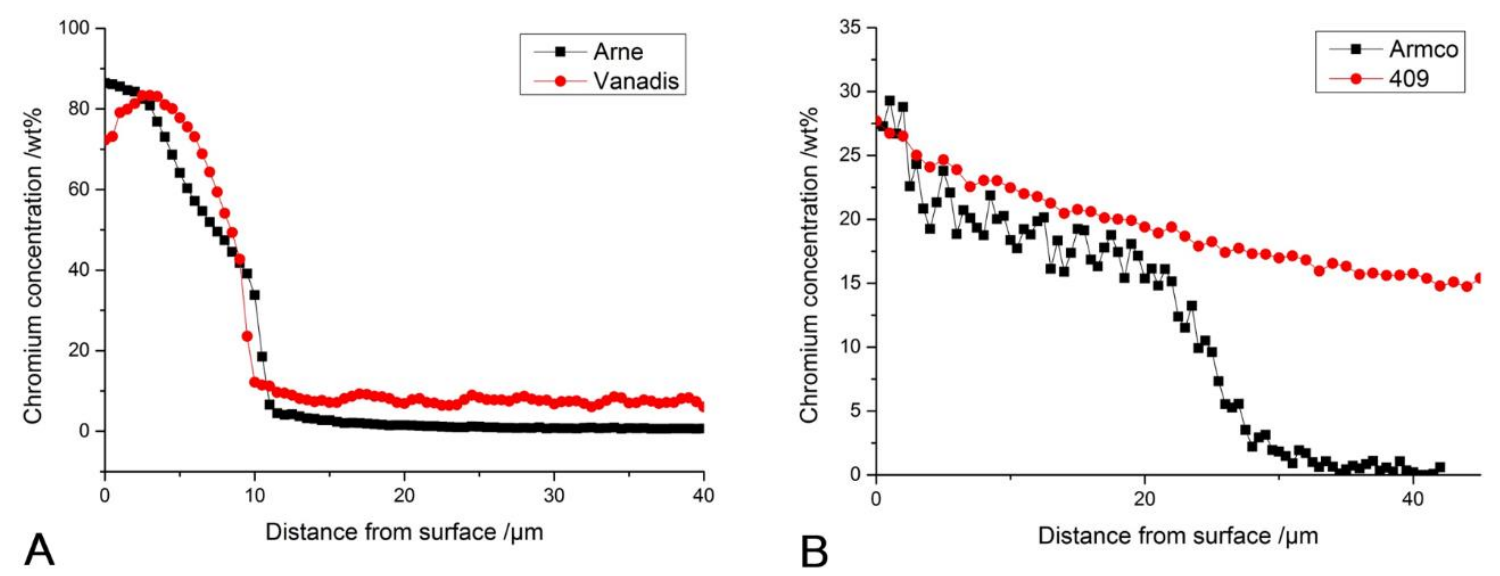
Fig.11

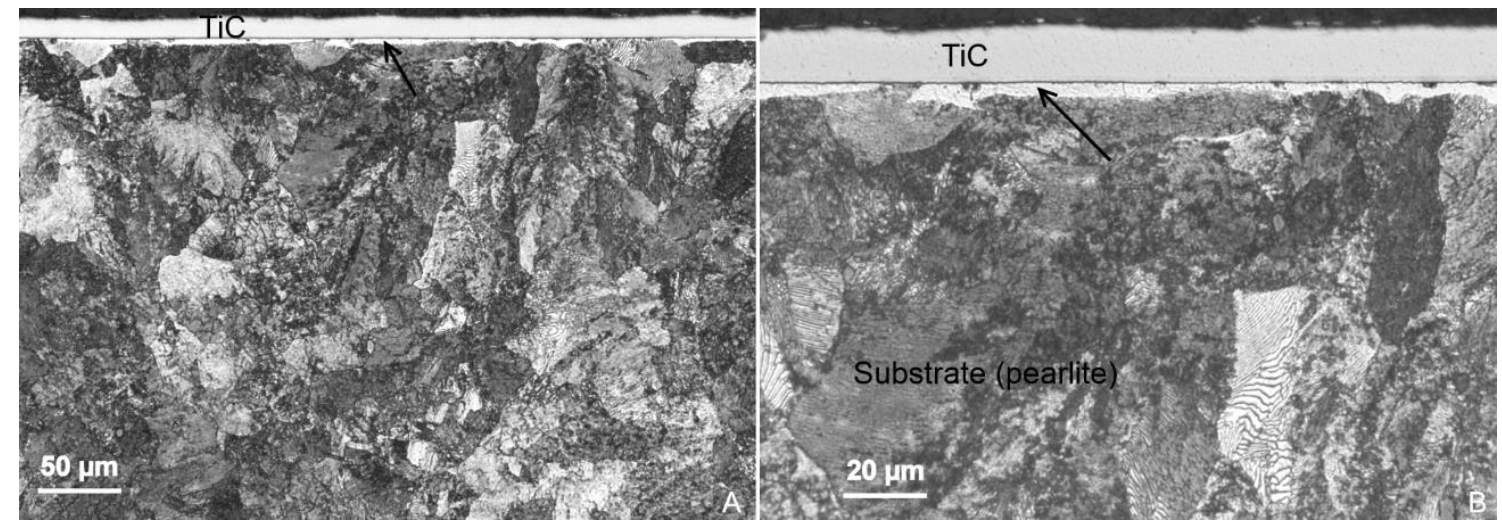


Fig.12

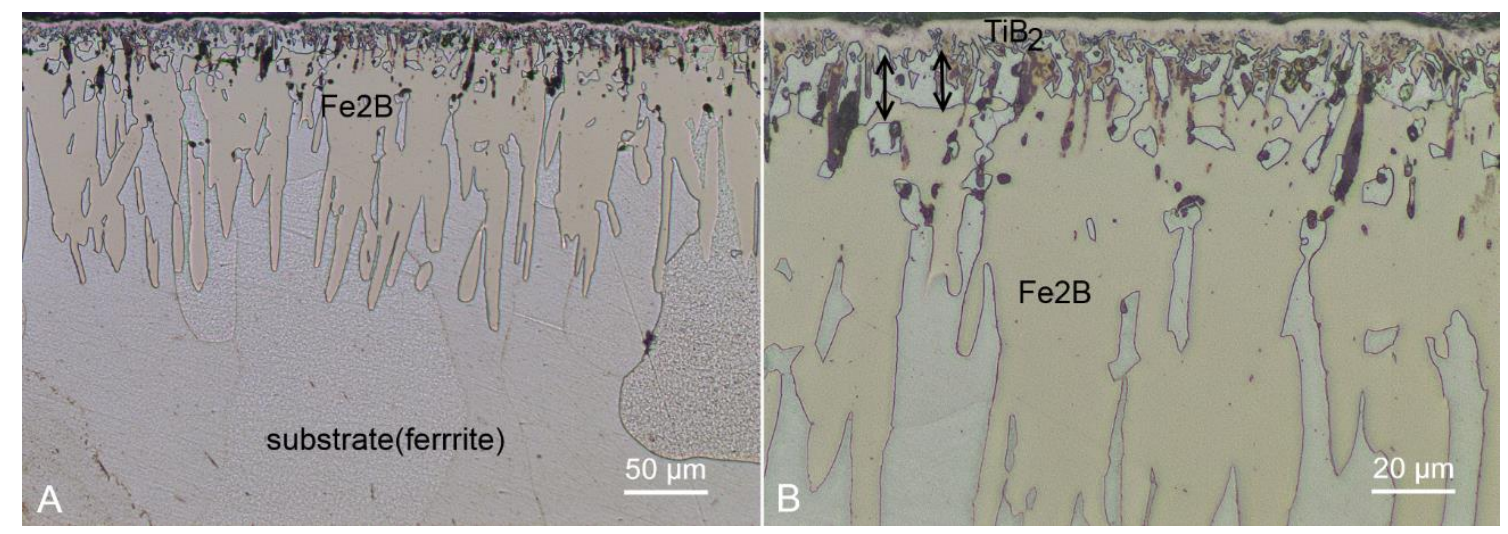


Fig.13

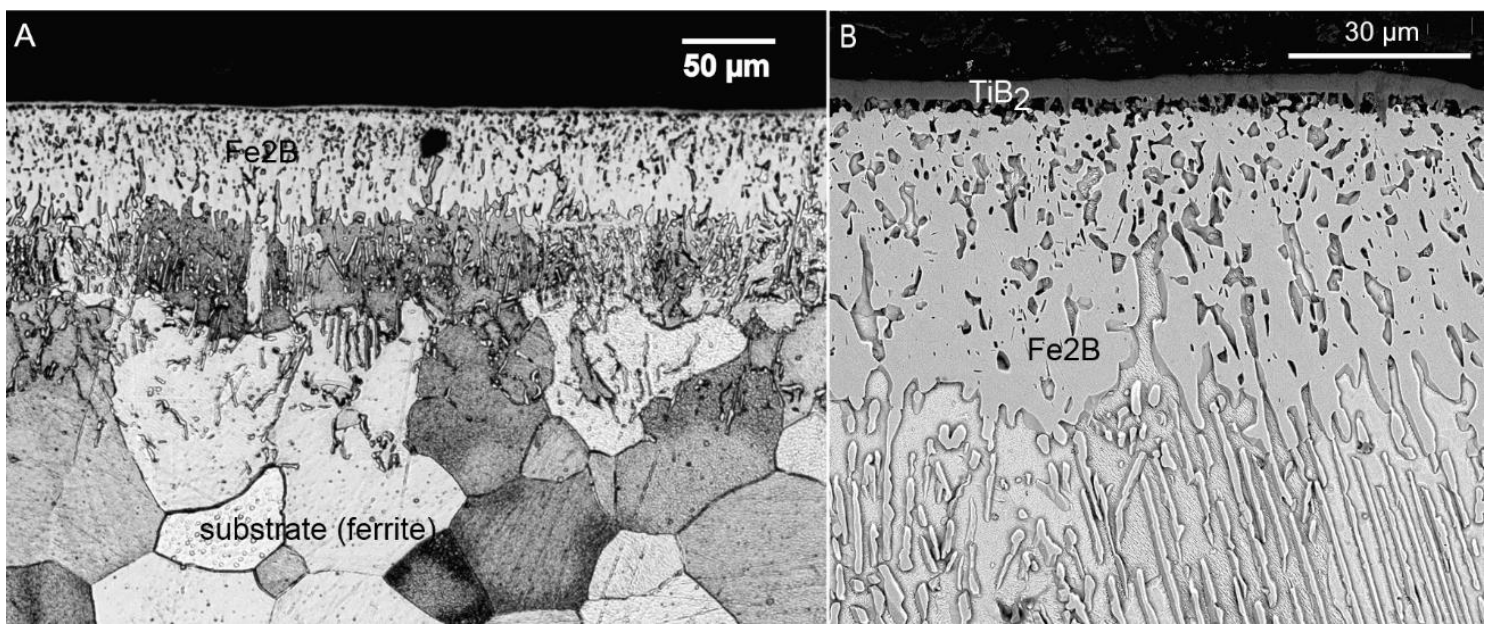

